\title{
Validation of a UV-VIS Spectrophotometric method for the determination of usnic acid /collagen-based membranes
}

\author{
Validação de um método analítico por espectrofotometria UV para quantificação de ácido \\ úsnico em membranas bioativas de colágeno
}

\author{
P. S. Nunes ${ }^{1 *}$; D. C. Jesus ${ }^{2}$; M. S. Bezerra ${ }^{2}$; J. C. C. Souza ${ }^{2}$; F. A. Silva ${ }^{2}$; M. R. \\ Serafini $^{2}$; B. S. Lima ${ }^{2}$;. Shanmugan ${ }^{2}$; R. L. C. Albuquerque-Júnior ${ }^{3}$; A. A. S. \\ Araújo $^{2 *}$ \\ ${ }^{I}$ Departamento de Morfologia/Laboratório de Anatomia e Embriologia do Desenvolvimento, Universidade Federal \\ de Sergipe, CEP 49000-100, São Cristóvão-Sergipe, Brasil \\ ${ }^{2}$ Departamento de Farmácial Laboratório de Ensaios Farmacêutico e Toxicidade, Universidade Federal de \\ Sergipe, CEP 49000-100, São Cristóvão-Sergipe, Brasil \\ ${ }^{3}$ Instituto de Tecnologia e Pesquisa, Universidade Tiradentes, CEP 49032-490, Aracaju-Sergipe, Brazil. \\ *paulanunes_se@yahoo.com.br
}

(Recebido em 22 de maio de 2015; aceito em 25 de julho de 2015)

\begin{abstract}
$\mathrm{O}$ ácido úsnico (AU) é um metabólito secundário de líquens que tem demonstrado potenciais efeitos farmacológicos, tais como atividade antimicrobiana, antiviral, antiproliferativa e anti-inflamatória. O colágeno, por sua vez, é um dos biomateriais mais utilizados visando o desenvolvimento de sistema de liberação de fármacos. Sendo assim, o objetivo deste estudo foi desenvolver e validar um método analítico por espectrofotometria na região do ultravioleta (UV) para determinação de concentrações de AU em membranas de colágeno. Os parâmetros de validação foram determinados de acordo com a Agência Nacional de Vigilância Sanitária (ANVISA). A especificidade revelou que os excipientes na formulação não interferiram na análise. A linearidade nas concentrações de $2-10 \mu \mathrm{g} / \mathrm{mL}$ apresentou um coeficiente de correlação de 0,9994 . O método mostrou excelente repetibilidade (desvio-padrão relativo < $1,0 \%$ ). A precisão revelou uma recuperação média percentual de $100,43 \%$. O método foi robusto para a variação de temperatura e solvente. Os limites de detecção e de quantificação foram 0,109 e $0,364 \mathrm{~g} / \mathrm{mL}$, respectivamente. A taxa total de recuperação das membranas analisados apresentaram valores entre 100,4 e $83,2 \%$.

Palavras-chave: ácido úsnico, membranas de colágeno, espectrofotometria UV
\end{abstract}

The usnic acid (UA) is a secondary metabolite of lichen that has shown potential pharmacological effects such as antimicrobial, antiviral, antiproliferative and anti-inflammatory activities. Collagen is one of the most useful biomaterials with various applications as drug delivery systems. The aim of this study was to develop and validate a quantitative UV spectrophotometric method for the determination of UA levels in collagen membranes. The validation parameters were assessed according to the Brazilian Health Surveillance Agency (ANVISA). The specificity revealed that the excipients in the formulation did not interfere with the analysis. The linearity in the range of $2-10 \mu \mathrm{g} / \mathrm{mL}$ presented a correlation coefficient of 0.9994. The method showed excellent repeatability (Relative Standard Deviation (RSD) $<1.0 \%$ ). The accuracy revealed a mean percentage recovery of $100.43 \%$. The method was robust for the variation of temperature and solvent. The detection and quantization limits were found at 0.109 and $0.364 \mu \mathrm{g} / \mathrm{mL}$. The total rate recovery from the analyzed membranes showed values between 100.4 and $83.2 \%$.

Keywords: Usnic acid, Collagen membranes, UV Spectrophotometry.

\section{INTRODUCTION}

A wide variety of wound dressings is developed using natural polymers, and some of them are successful in various biomedical applications. Materials such as hyaluronic acid, fibrin, fibrinogen and collagen have been tested as carriers for drug delivery systems [1, 2, 3]. Collagen 
is a potentially useful biomaterial since it is a major constituent of the connective tissue. The main applications of collagen as drug delivery systems are collagen-shields in ophthalmology, sponges for burns/wounds and liposome collagen associations for transdermal and sustained drug delivery $[4,5,6]$.

Usnic acid (UA), [2,6-diacetyl-7,9-dihydroxy-8,9b-dimethyl-1,3(2H,9bH)-dibenzofurandione; $\mathrm{C}_{18} \mathrm{H}_{16} \mathrm{O}_{7}$ ], is a yellow cortical pigment found only in lichens, occurring under two enantiomeric forms [7, 8]. As previously reported, usnic acid is one of the most common and abundant lichen metabolites with interesting activities. The biological activities of usnic acid have been studied and tested, such as antimicrobial [9,10], antitumoral [11, 12], antiinflammatory [13, 14], antioxidant [15, 16] and cicatricial [17].

Formulations such as ointments and wound dressings have been developed for the treatment of severe skin wounds or ulcers including bedsores and burn wounds [18, 19]. These studies generally involved the development and/or the physical characterization of the materials. Besides, some studies have been carried out in order to incorporate bioactive compounds into collagen-based membranes, so that such membranes could work as a drug controlled release within the target tissues [6,21]. The aim of this study was to prepare a collagen-based membranes composed by usnic acid-loaded liposomes and also to develop an easy, reproducible and accurate UV-spectrophotometric method for quantifying the usnic acid in collagen membranes, determining the main validation parameters for this complex matrix.

\section{EXPERIMENTAL}

\section{Reagents}

Methanol (HPLC grade, Merck, Darmstadt, Germany), glacial acetic acid (Synth, São Paulo, Brazil) and HPLC grade water (Milli-Q system, Millipore, Bedford, MA, USA) were used to the mobile phase preparation. Usnic acid (standard) was acquired from Sigma-Aldrich (Steinheim, Germany).

\section{Apparatus}

Shimadzu UV 1800 spectrophotometer with $1 \mathrm{~cm}$ path length quartz cell was used for absorption measurements.

\section{Extraction and purification of usnic acid}

Usnic acid, 2,6-diacetyl-7,9-dihydroxy-8,9b-dimetyl-1,3 (2H,9bH)-dibenzo-furandione, was isolated from Cladonia substellata Vainio collected in the Itabaiana, Sergipe-SE, Brazil. Lichen sample was identified by M. P. Marcelli (Botanical Institute of São Paulo-SP, Brazil), where a voucher specimen was deposited (Deposit \#SP393249). All chemicals were of reagent grade. Air-dried lichen $(300 \mathrm{~g})$ was extracted with diethyl ether in a Soxhlet apparatus and the precipitate formed on cooling was collected, recrystallized from ethanol, yielding the usnic acid.

\section{Membranes preparation}

Collagen-based membranes (CF) were prepared by casting the method using collagen dispersion (2\%) in $0.5 \mathrm{M}$ acetic acid with $20 \%$ of plasticizer (polyethylene glycol-PEG 1500 Isofar Lot. 021423) in relation to the polymer dry weight. This dispersion was cast onto a clean rimmed perspex plate and allowed to dry at room temperature in order to obtain the membranes. Usnic acid-loaded liposomes (UAL) were prepared in the conventional rotary evaporation method. Details of the method are described by Nunes et al. [22]. 


\section{Usnic Acid Standard Solution}

A methanolic primary stock solution of UA $(5.0 \mathrm{mg})$ was prepared in methanol. All the measurements were performed at room temperature. The standard solutions were prepared by the proper dilution of the primary stock solution with methanol to obtain working standard. The absorbance of these solutions was fitted in the calibration curve to calculate the accuracy and precision of the method.

\section{Standard curve}

UA standard was dissolved in methanol-water $(50: 50, \mathrm{v} / \mathrm{v})$ yielding concentrations of 2.0; $4.5 ; 6.0 ; 8.0$ and $10.0 \mu \mathrm{g} / \mathrm{mL}$. The solutions were filtered through a $0.45 \mu \mathrm{m}$ membrane filter (Millipore, HVHP). The results were expressed by the mean of peak areas obtained from three injections.

\section{Validation}

The validation of the analytical method included the determination of specificity, linearity, repeatability, intermediary precision and accuracy according to the International Conference on the Harmonization (ICH) guideline and ANVISA [23, 24].

\section{Specificity}

The specificity of the UV spectrophotometric method was evaluated through the analysis of a placebo solution. The placebo consisted of all the excipients without the active ingredient. The system response was examined through the presence of interference or overlaps with the UA absorbance.

\section{- Linearity}

The analytical curves were obtained with five concentrations of UA reference solution in the range of 2-10.0 $\mu \mathrm{g} \cdot \mathrm{mL}^{-1}$ for the spectrophotometric method. Each solution was prepared in triplicate. The linearity was evaluated with linear regression analysis through the least-square regression method, which was used to calculate the correlation coefficient, y-intercept and slope of the regression line. The limits of detection (LOD) and limits of quantitation (LOQ) were calculated based on the relative standard deviation (RSD) and the slope (S) of the standard calibration curves $[23,24]$.

\section{- Precision}

The precision of the procedures was determined by repeatability (intra-day) and intermediate precision (inter-day). The precision of the method was evaluated through the determination of the repeatability (intra-day) and intermediary precision (inter-day). Repeatability was evaluated assaying six determinations at the same concentration $\left(6.0 \mu \mathrm{g} . \mathrm{mL}^{-1}\right)$, during the same day, under the same experimental conditions. Intermediate precision was analyzed comparing the assays in six determinations at the same concentration $\left(6.0 \mu \mathrm{g} \mathrm{mL}^{-1}\right)$ during three different days. Precision (repeatability and intermediate precision) was expressed as relative standard deviation (RSD\%).

\section{- Accuracy}

The accuracy was evaluated through recovery studies by adding known amounts of UA to collagen-based membranes (CF). The placebo solution without the standard addition was analyzed as control. The assay was performed at three different concentrations of standard solution $\left(4.0,6.0\right.$ and $8.0 \mu \mathrm{g} \mathrm{mL} \mathrm{m}^{-1}$ ), at three different levels (lower, medium and upper 
concentration) three times each. The recovery was determined by subtracting the values obtained for the control samples from those samples that were prepared with the added standards, divided by the amount added and multiplied by $100 \%$ and also expressed as the relative standard deviation ( $\mathrm{RSD} \%)$ between the measurements [23, 24].

\section{- Robustness}

The robustness of the method was determined by the analysis of samples under a variety of conditions such as small changes in the temperature $\left(4\right.$ and $\left.25^{\circ} \mathrm{C}\right)$ and employed different methanol manufacturers named $\mathrm{A}$ and $\mathrm{B}$, respectively). The robustness assessment was performed by analyzing the coefficients of variation of the averages obtained, using T-test ( $p$ $<0.05)$.

\section{Sample preparation for spectrophotometric analysis}

The UAL was placed in chloroform-methanol $(3: 1 \mathrm{v} / \mathrm{v})$ in volumetric flasks of $10 \mathrm{~mL}$. The mixture was stirred and sonicated for $5 \mathrm{~min}$ at the same time. Finally, the mixture was diluted with methanol for drug assay through ultraviolet spectrophotometry at $290 \mathrm{~nm}$.

\section{HPLC conditions}

The HPLC analysis were performed on a Shimadzu system consisting of a degasser DGU-20A3, a SIL-20A autosampler, two LC-20AD pumps and a SPDM20Avp photodiode array detector (DAD), coupled with a CBM20A interface. The column used was a Phenomenex Luna C18 analytical column $150 \times 4.6 \mathrm{~mm}$. The flow rate was $1.0 \mathrm{~mL} / \mathrm{min}$ and the injection volume was $20 \mu \mathrm{L}$. The mobile phase used was methanol - acetic acid:water $1.0 \%(\mathrm{v} / \mathrm{v})$ (90:10). The detection wavelength was $350 \mathrm{~nm}$ (photodiode array detector). The HPLC method was used to compare the method from a standard solution of usnic acid.

\section{RESULTS AND DISCUSSION}

The UV method for the assay of usnic acid/ collagen-based membranes was developed as an alternative technique, considering its rapid and low cost as well as its simple instrumentation compared to chromatographic techniques.

\section{Specificity}

The first analytical experiments were performed in order to evaluate whether membranes excipients could interfere with the UA quantification. The mobile phase composition, as well as the other chromatographic conditions, was chosen in order to obtain efficient routine analysis. The specificity was carried out through the comparison of the UV spectra of the UA and blank membranes). No interference of the membrane excipients was noticed since no peak was detected after the analysis of the blank membranes at set wavelengths (Figure 1). 


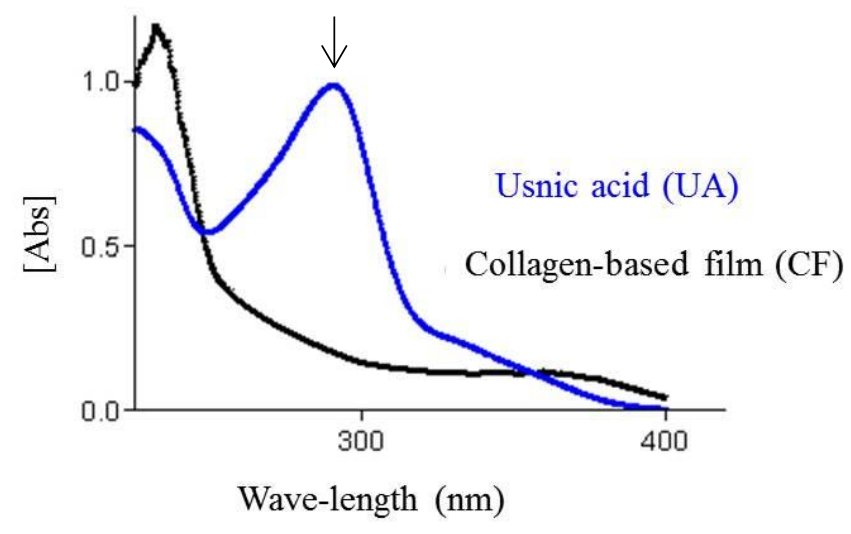

Figure 1: Absorption spectra of the usnic acid (UA) and blank membrane (CF). The arrow ( $\downarrow)$ indicates the detection wave-length at which maximum absorbance was observed.

\section{Linearity}

For the experimental conditions described previously, linear regression equation was established from the calibration. The usnic acid concentration showed a linear relationship between the absorbance at $290 \mathrm{~nm}$ and the concentration range with correlation coefficient $(\mathrm{r})$ higher than 0.9994 (Figure 2 and Table 1). Moreover, the F-values calculated did not exceed the tabulated values at $5 \%$ significance levels, proving the linearity of the calibration graphs and the conformity with Lambert-Beer law for both systems. The LOD and LOQ UA were, respectively, of $0.109 \mu \mathrm{g} / \mathrm{mL}$ and $0.364 \mu \mathrm{g} / \mathrm{mL}$. Therefore, the results show that the method presents good sensitivity for the standard analyzed.

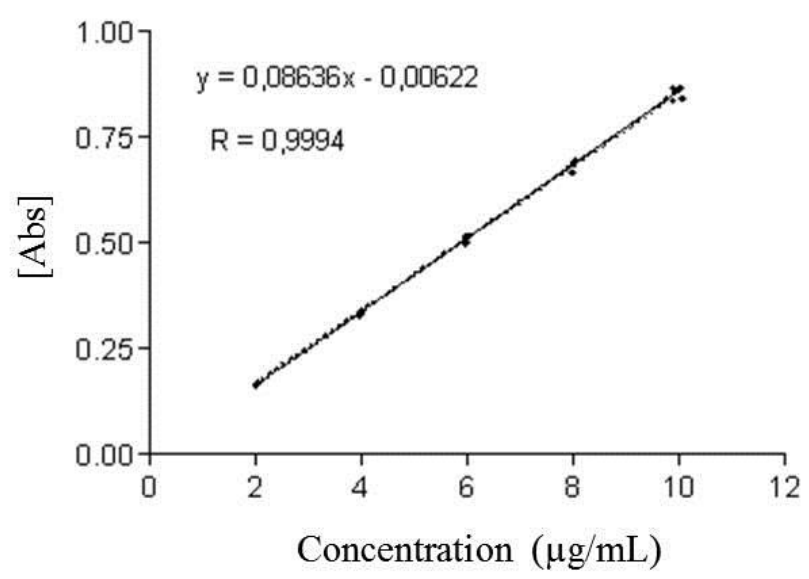

Figure 2: Calibration curve for absorbance (Abs) vs. concentration $(\mu \mathrm{g} / \mathrm{ml})$ of usnic acid showing the linearity of the assay over the calibration range.

Table 1. Details of the analytical curve of usnic acid.

\begin{tabular}{ccc}
\hline $\begin{array}{c}\text { Usnic acid concentration } \\
(\boldsymbol{\mu g} / \mathbf{m L})\end{array}$ & Absorbance mean $( \pm$ RSD $)$ & $\begin{array}{c}\text { Concentration calculated usnic } \\
\text { acid }( \pm \text { RSD })\end{array}$ \\
\hline 2 & $0.168 \pm 0.002$ & $2.014 \pm 0.020$ \\
4 & $0.339 \pm 0.003$ & $3.987 \pm 0.020$ \\
6 & $0.510 \pm 0.008$ & $5.987 \pm 0.029$ \\
8 & $0.684 \pm 0.013$ & $8.004 \pm 0.025$ \\
10 & $0.857 \pm 0.013$ & $10.008 \pm 0.040$ \\
\hline
\end{tabular}

RSD = Relative Standard Deviation 


\section{Precision}

Repeatability experiment was performed the intra-day precision with nine repetitions at each of the levels at $6.0 \mu \mathrm{g} \cdot \mathrm{mL}^{-1}$, using the same solutions. The data were evaluated by one-way analysis of variance (ANOVA). The standard deviation (\%) lower than 0.32 demonstratedreproducibility and, thus, the low interference of the sample preparation step. These values can be considered excellent for analytical procedures [23, 24] (Table 2).

Table 2. Repeatability test for the usnic acid reference substance of UV-VIS Spectrophotometric method.

\begin{tabular}{lcc}
\hline & Absorbance $(\mathbf{2 9 0} \mathbf{~ n m})$ & Concentration $(\boldsymbol{\mu g} / \mathbf{m L})$ \\
\hline 0.513 & 6.012 \\
& 0.518 & 6.070 \\
& 0.516 & 6.047 \\
& 0.515 & 6.035 \\
& 0.516 & 6.047 \\
& 0.515 & 6.035 \\
& 0.516 & 6.047 \\
& 0.518 & 6.070 \\
\hline Mean & 0.514 & 6.023 \\
RSD & 0.515 & 6.042 \\
RSD (\%) & 0.002 & 0.019 \\
\hline RSD $=$ Re & 0.321 & 0.320 \\
\hline
\end{tabular}

RSD = Relative Standard Deviation

\section{Accuracy}

The accuracy of the method was determined with the recovery test. The results (Table 3) indicate recovery rates for UA of $100.43 \%$ with RSD \% lower than $1.0 \%$ in all concentrations analyzed, indicating a good agreement between amounts added and found.

Table 3. Recovery test for usnic acid standard substance through UV-VIS Spectrophotometric method.

\begin{tabular}{lcccccc}
\hline $\begin{array}{c}\text { Theoretical } \\
\text { concentration } \\
(\boldsymbol{\mu g} / \mathbf{m L})\end{array}$ & $\begin{array}{c}\text { Experimental concentration } \\
(\boldsymbol{\mu g} / \mathbf{m L})\end{array}$ & Mean & RSD & RSD $(\%)$ \\
\hline 4.0 & 4.043 & 4.032 & 3.974 & 4.016 & 0.037 & 0.923 \\
6.0 & 6.047 & 6.035 & 6.023 & 6.035 & 0.012 & 0.198 \\
8.0 & 8.038 & 8.015 & 8.027 & 8.026 & 0.011 & 0.137 \\
\hline
\end{tabular}

RSD = Relative Standard Deviation

\section{Robustness}

Influences of small changes in UV-VIS spectrophotometric method were studied to determine robustness of the method. Usnic acid absorvances spectrum changes were observed. No significant difference could be observed in the results found out. The results can be seen on Table 4. 
Table 4. The influence of small changes in UV-VIS (robustness method).

\begin{tabular}{lccc}
\hline & & $\mathbf{T}_{\text {values }}$ & \\
Temperature & Methanol manufacturers & $\mathbf{T}_{\text {test }}$ \\
$04^{\circ} \mathrm{C}$ and $23^{\circ} \mathrm{C}$ & A and B & \\
\hline$p \quad 0.182$ & 0.197 & 4.3 \\
\hline Significant for $\alpha=0.05$ &
\end{tabular}

\section{Analysis of collagen-based membranes $(C F)$}

The optimized UV-spectrophotometric method was applied for the determination of UA in collagen membranes using calibration curve method. The results show that the proposed method was successfully applied for the assay of UA in membranes formulation.

It was seen that there was no suitable mass homogeneity in the samples supplied, and a difference in mass could be observed between the membrane at the concentration of $50 \%$ and the membrane at the concentration of $100 \%$, both with propylene glycol in the composition. In the two types of biomembrane, the mass average of usnic acid obtained was close to the concentrations of 25 and $50 \%$, even though the expected was a proximity of two-fold the concentration of $50 \%$ compared to the concentration of $25 \%$.

It was observed that in all membranes, the variation coefficient of the usnic acid recovered was high, highlighting the membranes at the concentration of $100 \%$, which presented $32.87 \%$ for the biomembrane with PEG and $23.08 \%$ for the biomembrane with propylene glycol. Once can see that such values are high, indicating that there has not been a suitable adequacy of the drug in the biomembrane extension.

The total recovery rate for UA was also evaluated and showed values between 100.4 and $82.3 \%$ (Table 5).

Table 5. Determination of usnic acid in collagen membranes

Usnic acid concentration $(\mu \mathrm{g} / \mathrm{mL})$

\begin{tabular}{ccc}
\hline Theoretical & Experimental (RSD) & Recovery (\%) \\
\hline 3.0 & $3.14(0.07)$ & 100.4 \\
6.0 & $5.53(0.34)$ & 88.5 \\
12.0 & $10.28(0.44)$ & 82.3 \\
\hline
\end{tabular}

RSD = Relative Standard Deviation

\section{HPLC results}

Usnic acid retention time in this method was 7.5 min (Figure 3), an adequate retention time for drug. This experiment was conducted in order to prove the usnic acid content using another method. The peak is below an assay at a concentration of $10 \mu \mathrm{g} / \mathrm{mL}$. 


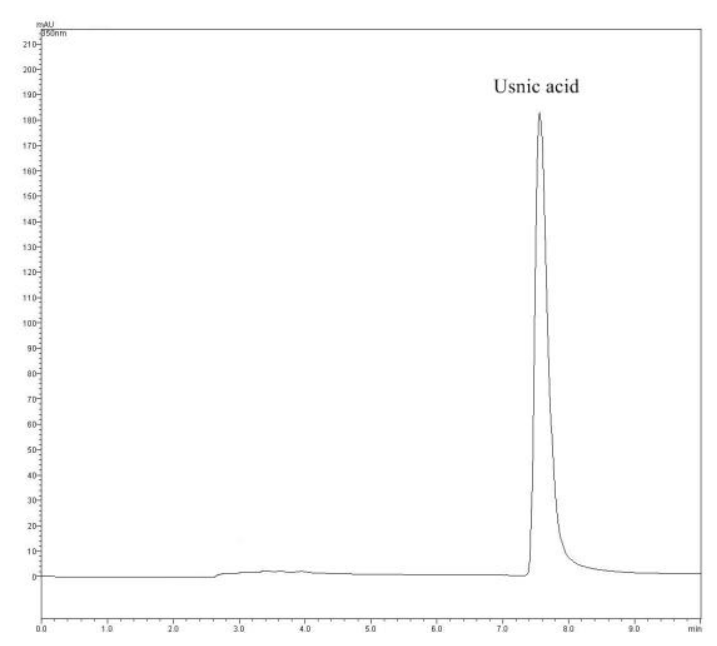

Figure 3: HPLC chromatogram of usnic acid (A), using mobile phase of methanol-acetic acid:water 1.0 $\%(\mathrm{v} / \mathrm{v})(90: 10)$ with a flow rate of $1.0 \mathrm{~mL} \cdot \mathrm{min}^{-1}$ and detection wavelength of $350 \mathrm{~nm}$.

\section{CONCLUSIONS}

A UV-spectrophotometric method for quantifying the usnic acid in sample formulation of membranes has been developed and validated. The assay is selective, precise, accurate and linear over the concentration range studied. In summary, the proposed method can be used for the drug analysis in routine quality control.

\section{ACKNOWLEDGEMENTS}

The authors thank the financial support of CNPQ (Conselho Nacional de Desenvolvimento Científico e Tecnológico)/Brazil.

\section{REFERENCES}

1. Dias RCM. Síntese, caracterização e avaliação preliminar de citotoxicidade da matriz porosa de nanocompósito biodegradável. Dissertação de Mestrado. Engenharia Metalúrgica e de Minas. Universidade Federal de Minas Gerais, 2006.

2. Jin G, Prabhakaran MP, Kai D Annamalai SK, Arunachalam KD, Ramakrishna S. Tissue engineered plant extracts as nanofibrous wound dressing. Biomaterials. 2013; 34: 724-734.

3. Mendes Júnior ECS, Viterbo F, Rosa CS. Análise histológica e morfométrica da área cruenta tratada com membrana de silicone: estudo em ratos. Revista da Associação Médica Brasileira. 2007; 53(5): 395-400.

4. Ahmad M, Benjakul S, Prodpran T, Agustini TW. Physico-mechanical and antimicrobial properties of gelatin film from the skin of unicorn leatherjacket incorporated with essential oils. Food Hydrocolloids. 2012; 28: 18-199.

5. Zaman HU, Islam JMM, Khan MA, Khan RA. Physico-mechanical properties of wound dressing material and its biomedical application. Jounal of the mechanical behavior of biomedical materials. 2011; 4: 1369-1375.

6. Parenteau-Bareil R, Gauvin R, Cliche S, Gariépy C, Germain L, Berthod F. Comparative study of bovine, porcine and avian collagens for the production of a tissue engineered dermis. Acta Biomaterial. 2011; 7: 57-65.

7. Henssen A, Jahns M. Lichenes. Georg Thieme Verlag, Stuttgart, 1974; 467.

8. Bazin M, Lamer A, Delcros G, Rouaud I, Philippe Uriac P, Joël Boustie J, Corbel J, Tomasi S. Synthesis and cytotoxic activities of usnic acid derivatives. Bioorganic \& Medicinal Chemistry. 2012; 16: 60-66.

9. Gupta VK, Verma S, Gupta S, Singh A, Pal A, Srivastava SK, Srivastava PK, Singh SC, Darokar MP. Membrane-damaging potential of natural L (-) usnic acid in Staphylococcus aureus. European Journal Clinical Microbiology and Infection Disorder. 2012; 31 (12):3375-83. 
10. Segatore B, Bellio P, Setacci D, Brisdelli F, Piovanob M; Garbarino JA, Nicoletti M, Amicosante G, Perilli M, Celenza G. In vitro interaction of usnic acid in combination with antimicrobial agents against methicillin-resistant Staphylococcus aureus clinical isolates determined by FICI and $\Delta E$ model methods. Phytomedicine. 2012; 19: 341-347.

11. Backorova M, Jendzelovsky R, Kello M, Backor M, Mikes J, Fedorocko P. Lichen secondary metabolites are responsible for induction of apoptosis in HT-29 and A2780 human cancer cell lines. Toxicology in Vitro. 2012; 26: 462-468.

12. Russo A, Piovano M, Lombardo L, Garbarino J, Cardile V. Lichen metabolites prevent UV light and nitric oxide-mediated plasmid DNA damage and induce apoptosis in human melanoma cells. Life Sciences. 2008; 83: 468-474.

13. Vijauakumar CS, Viswanathan S, Reddy MK, Parvathavarthini S, Kundu AB, Sukumar E. Antiinflamatory activity of (+)-usnic acid. Fitoterapia. 2000; 71 (5): 564-566.

14. HUANG S. Liposomes in ultrasonic drug and gene delivery. Advanced Drug Delivery Review. 2008; 60: $1167-1176$.

15. Melo MG, Dos Santos JP, Serafini MR, Caregnato FF, Pasquali MA, Rabelo TK, Da Rocha RF, Quintans Júnior LJ, Araújo ASA, Da Silva FA. Redox properties and cytoprotective actions of atranorin, a lichen secondary metabolite. Toxicology In Vitro. 2011 (B); 25: 462-468.

16. Rabelo TK, Zeidán-Chuliá F, Vasques LM, Santos JPA Dos, Rocha RF, Pasquali MAB, RybarczykFilho JL, Araújo ASA, Moreira JCF, Gelain DP. Redox characterization of usnic acid and its cytotoxic effect on human neuron-like cells (SH-SY5Y). Toxicology in Vitro. 2012; 26: 304-314.

17. Nunes PS, Bezerra MS, Albuquerque-Júnior RLC, Cavalcante DRR, Dantas MDM, Cardoso JC, Souza JCC, Serafini MS, Quitans-Jr LJ, Bonjardim LR, Araújo ASA. Collagen-Based Films Containing Liposome-Loaded Usnic Acid as Dressing for Dermal Burn Healing. Journal of Biomedicine and Biotechnology. 2011; 12(1): 9-14.

18. Bernales DM, Caride F, Lewis A, Martin L. Membranas de colágeno polimerizado: consideraciones sobre su uso en técnicas de regeneración tissular y ósea guiadas. Rev Cubana Invest Biomed. 2004; 23(2): 65-74.

19. Elsner JJ, Egozi D, Ullmann Y, Berdicevsky I, Shefy-Peleg A, Zilberman M. Novel biodegradable composite wound dressings with controlled release of antibiotics: Results in a guinea pig burn model. Burns. 2011; 37: 896-904.

20. Lee TWY, Robinson JR. Remington's Pharaceutical Sciences, 20 a ed. Rio de Janeiro: Guanabara Koogan. 2004; 933-960.

21. Cardoso JC, 2005. Desenvolvimento de gel a partir de colágeno modificado para liberação prolongada de fármacos. Dissertação (Mestrado em Ciências Farmacêuticas) Universidade de São Paulo, Faculdade de Ciências Farmacêuticas de Ribeirão Preto.

22. Nunes PS, Bezerra MS, Costa LP, Cardoso JC, Albuquerque-Júnior RLC, Rodrigues MO, Barin GB, Silva FA, Araújo AAS.Thermal characterization of usnic acid/collagen-based films. Journal of Thermal Analisys and Calorimetry. 2010; 99: 1011-1014.

23. International Conference on Harmonisation (ICH); Validation of Analytical Procedures: Methodology, Q2B (CPMP/ICH/281/95), 1995.

24. Agência Nacional de Vigilância Sanitária (ANVISA); Resolução RE no 899, de 29/05/2003. 